HISTORY OF MEDICINE

\title{
Transfer of hospitals and "additional premises" to the state: questionable morality in the implementation of the National Health Service Act (1946)
}

\section{G C Cook}

Postgrad Med J 2004;80:716-719. doi: 10.1136/pgmj.2003.016089

The National Health Service Act of 1946, pioneered by Aneurin Bevan, came into being on the "appointed day", 5 July 1948. Hospitals with their "additional premises" throughout Britain were "seized" by the state and incorporated into this vast socialist enterprise. While the majority of the population welcomed this new initiative in the creation of a welfare state, associated with medical care from cradle to grave, not all (especially members of various Hospital Boards of Management) were so enthusiastic. The hospitals for "incurables" (long stay patients) were unhappy and lost a vast proportion of their income owing to a great deal of procrastination; but most of them ultimately managed to escape nationalisation after a prolonged period of negotiation, by a claim that they were "homes" rather than "hospitals". The confiscation of property which had been built as a result of voluntary subscription was another huge and highly contentious matter, which has been highlighted in recent years. The future of the Seamen's Hospital Society's properties represents a good example of this.

Correspondence to:

Professor Gordon C Cook, Fellowship of Postgraduate Medicine, 12 Chandos Street, London W1G 9DR, UK

Submitted

15 October 2003

Accepted

15 October 2003
A lthough the general plan of the proposed National Health Service (NHS) had been worked out by an all-party Government during the 1939-45 war, and was set out in the Beveridge plan before 1945, many details remained to be delineated..$^{1-3}$ Until 1945 (when the Labour party under Clement Attlee won a July election) hospital services in London were based upon the local authority-the London County Council and before it, the Metropolitan Asylums Board. ${ }^{45}$ Aneurin Bevan (fig 1) believed that the state should guarantee a free health service for all $^{6}$; this would of necessity exclude local authorities from a role in hospital management and at the same time deprive the voluntary hospitals of their traditional sources of income. With the exception of teaching hospitals (which were to have Boards of Governors directly accountable to the Minister), hospital services would be managed on his behalf by Regional Boards. Bevan had therefore come up with this wholly unexpected policy-that is, to nationalise all voluntary and local authority hospitals (fig 2).

In theory, the 14 "regions" would be based on university medical centres-the "natural focal points of specialist medicine, and therefore of the hospital services". The endowments of the voluntary hospitals were expected under Bevan's scheme to pass directly to the new Boards of Governors.

London's voluntary hospitals, at all levels, remained concerned about "seizure" of their premises by the state, together with their endowments and trust funds. There was also concern about regional boundaries. The major teaching hospitals had much potentially to gain; their financial state had after all been parlous in the interwar years, but had been somewhat improved by wartime subventions. Now peace had returned, the bulk of income came from state and local authority sources. ${ }^{2}$ It was the smaller voluntary hospitals which were in a far less satisfactory position; they would be run by local Regional Boards, and therefore lose much of their autonomy and independence. In addition, their financial position was at that time becoming increasingly precarious. The Minister gave his assurance that on the "appointed day" (5 July 1948), overdrafts as well as assets would be taken over by the Government.

As well as the 14 Regional Boards which oversaw the hospital services, the NHS also incorporated 140 executive councils - to deliver general medical, together with dental, pharmaceutical and ophthalmic services, as well as 146 local health authorities which provided ancillary services-for example, health centres, ambulances, health visitors, vaccination and maternity, and child health services.

Until 1945, the London Hospital System had evolved slowly and insidiously-from the Workhouse, the Metropolitan Asylums Board, and most recently London County Council control. So nationalisation brought with it a sharp arrest of this slow but progressive development. ${ }^{78}$ The problems facing Hospital Management Committees can be divided into immediate and long term ones. Examples of both will be given in this account.

\section{IMMEDIATE EFFECTS}

J A Wolfe, a barrister, and Honorary Counsel to the Home and Hospital for Jewish Incurables (HHJI) wrote from Lincoln's Inn on 18

Abbreviations: $\mathrm{BHH}$, British Home and Hospital for Incurables; HHJ, Home and Hospital for Jewish Incurables; NHS, National Health Service; RHHI, Royal Hospital and Home for Incurables; SHS, Seamen's Hospital Society 


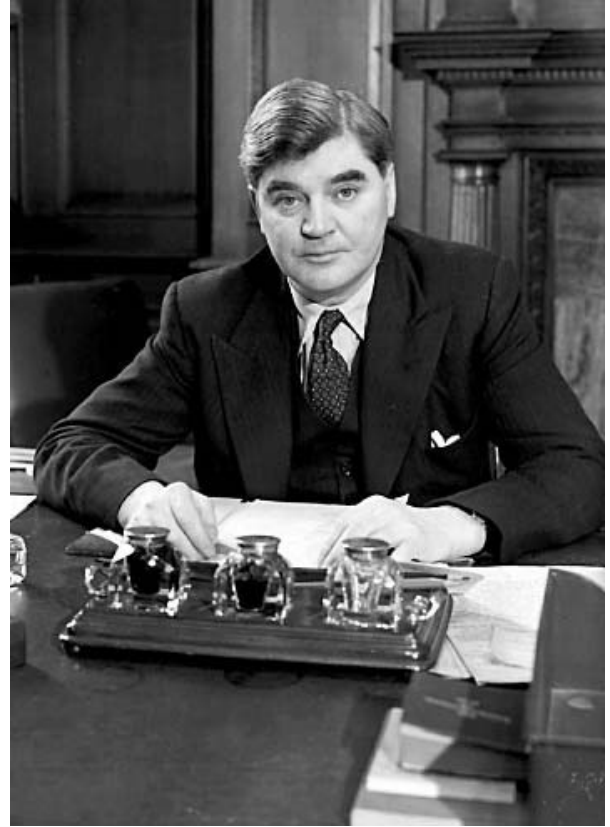

Figure 1 Aneurin Bevan (1897-1960) who was Minister of Health in Attlee's post-war government, and the architect of the NHS.

November 1947: "I am of opinion that the [HHJI, High Road, South Tottenham, N15] is not a 'hospital' as defined by Section 79 of the National Health Service [NHS] Act 1946 [this section provides definitions, for example, what is a hospital?] and accordingly that the provisions of that Act do not apply to it". He continued "Even if I am wrong in this view there seem to be good reasons on which the Minister [Bevan] can be asked to exercise his power of disclaimer under Section 6(3) of the Act" [which was concerned with the transfer of hospitals to the Minister]. ${ }^{9}$ He also produced a draft for a suggested letter addressed to The Secretary, Ministry of Health, for his "Instructing Solicitors"-the "Honorary Solicitor [Malcolm Slowe] to the [HHJI]". This letter, which was in fact in the form of a reply to one from the Secretary to the Ministry of Health to the HHJI solicitor, was duly sent on 19 November. $^{10}$

The reply from the Ministry of Health pointed out "that the Minister regards these premises [that is, the HHJI] as transferable to him... but is prepared to consider the suggestion that they should be disclaimed under Section 6(3)". The writer (Gedling) continued: "He [Bevan] is seeking the views of the (North-east metropolitan] Regional Hospital Board...". ${ }^{11}$ Gedling gave more detail in a further letter: "...it appears to the Minister that this institution is [my italics] a hospital as defined in Section 79(1) of the Act and is liable to be transferred to him". He continued: "...the Minister has decided not to disclaim it [under Section 6(3)]. He is ... anxious to preserve its present character as he is required to do under Section 61 of the Act [this Section was concerned with links to a particular religious denomination] and it is his intention that it should continue to be used for patients of the Jewish faith, and that its existing denominational character should be preserved". He added that the Regional Board agreed with this view. ${ }^{12}$

In a circular letter to the subscribers, with which he included a copy of Gedling's letter, Gilbert, the Secretary of the Jewish home, pointed out that:

(1) ..."since the Minister [will acquire] all the property of the Institution, there will be nothing to prevent him transferring our patients to another area if it was
I946.

National Healh Service Act, 1946 .

CH. 8r.

III9

GHAPTER 81.

National Health Service Act, 1946.

ARRANGEMENT OF SECTIONS.

PART I.

Central Administration,

Section. Duty of Minister.

2. Central Health Services Council and Standing Advisory Committees,

PAIRT II.

Hospital and Specialist Services.

Provision of Services by Ministcr.

1'Tovision of hospital and specialist services.

Accommodation available on part paymen:

Accommodation for private patients.

Transfer of hospitals to the Minister.

6. Transfer of hospitals to the Minister.

Endowments of voluntary hospitals.

Supplementary provisions relating to transfer of hospital property

and liabilities.
power to acquire hospital equipment.

Local administration of hospital anl specialist scrvices.

Reysional Hospital lioarcis, Hospital Mfanagement Committecs, and

Boards of Governors of tencling lospitals.

12. Functions of Boards and Management Committecs.

13. Legal status of Boards and Management Committec

15. Medical schools in London.

16. Ikesearch.

Ancillary services provided by the Minister.

17. Bacteriological service.

illood transfusion and other services.

I'MRT III.

He.atu Services Providrd by local Health Authorities.

19. Local health authoritics.

20. Proposals for provision of services by local health authority.

21. liealth Centres.

22. Care of mothers and young ciildren.

23. Nidwifery.

24. Health visiting.
25. Home nursing.

Figure 2 The National Health Service Act of 1946, which was implemented on 5 July 1948.

considered that the accommodation at the Home at Tottenham could be better utilised for another type of patient", and

(2) The promise to preserve the present character of the Home "will in no way be binding on any future Minister or even on the present Minister...". ${ }^{13}$

By April 1948, a definitive decision had apparently still not been taken by Bevan. Therefore, Slowe again wrote to the Secretary at the Ministry of Health requesting a ruling as a matter of urgency: "...There is reason to think that many intending donors have cancelled gifts and revoked or withheld legacies under the impression that the Home, not being included in the published list of exempt Institutions, will be acquired by the State, and the clerical staff is being put to great trouble in answering official inquiries which will be unnecessary if it turns out that the Home is outside the provisions of the Act. In addition, there is unsettlement and uncertainty among the staff". ${ }^{14}$

The opinion of J A Wolfe (see above) was at this point jointly confirmed by himself and Sir Cyril Radcliffe, KC, also of Lincoln's Inn. ${ }^{15}$ In July of that year, a meeting took place between Slowe, and solicitors representing the Royal Hospital and Home for Incurables (RHHI), Putney, and the British Home and Hospital for Incurables (BHHI); as Slowe wrote in a subsequent letter to Gilbert, since the HHJI's arbitration case was likely to come up first, the two other institutions would be watching with interest. He concluded this letter by saying that although the opinion of Sir Valentine Holmes, KC 
(RHHI) was favourable, that of Mr Havers, KC (BHHI) was not. ${ }^{16}$

In October 1948, Gilbert wrote to Slowe with two pieces of "confidential" information: (i) that the home would not be taken over, as the local Regional Board had concluded that it "could not alter the fundamental nature of the Home", and (ii) he had met the brother-in-law of the Stoke Newington MP (David Weitzman) who "is very friendly with Aneurin Bevan ...". ${ }^{17}$ In January 1950, Rabbi Israel Brodie, KBE (the Chief Rabbi) visited the Home, and wrote to Bevan requesting "an early interview". ${ }^{18}$

Eventually, the arbitration proceedings took place, but not until February/March 1950! The proceedings were heard by Harold Alfred Hunter Christie, KC, of Lincoln's Inn, who ruled that: "...none of the interests held by the Trustees immediately before the 5th July 1948 [the 'appointed day'] in or attaching to the premises [of the HHJI], or in equipment furniture or other movable property used in or in connection with the said premises and none of the rights and liabilities incurred or acquired by the Trustees or to which they were entitled or subject solely for the purpose of managing the said premises or carrying on the business [of the HHJI] were either transferred to or vested in the Minister under Section 6(1) of the National Health Service Act 1946 on the 5th July $1948^{\prime \prime}$. Christie also awarded costs to the HHJI. ${ }^{19}$

The result of the arbitration proceedings had thus been entirely in favour of the HHJI, but the sum total was that not only this, but all of the institutions for incurables, including the RHHI, ${ }^{20}$ (most of which won their arbitration proceedings) had, during this period of great uncertainty, lost a great deal of financial income-from both subscribers and other benefactors.

\section{LONG TERM CONSEQUENCES}

On the "appointed day" the Minister (Bevan) had also "seized" all of the Seamen's Hospital Society (SHS)'s hospitals-which included not only the Dreadnought at Greenwich but also the Albert Dock Hospital, as well as the Convalescent Home (at Cudham) and the Sanatorium (at Bramshott). These all fell under different Regional Boards and this act of "vandalism" virtually decimated this great charity which had been in existence since $1821 .^{21} 22$

In late 1954 (that is, six years after inauguration of the NHS), Sir Ernest Murrant ${ }^{23}$ wrote, as Chairman of the Board of Management of the SHS, to the then Minister of Health, Iain MacLeod. ${ }^{24}$ The objects of his letter were to express his Board's views, and to attempt to obtain the truth about a new lease for a term of $71 \frac{1}{2}$ years, which his Ministry had both negotiated (and accepted) from the Admiralty in respect of both the Dreadnought Hospital and the "additional premises" (that is, the Devonport Nurses' Home (fig 3) and Devonport Pathological Laboratory) at Greenwich. ${ }^{25}$ These "additional premises" had been built between 1926 and 1929 by the SHS (for "purposes beneficial to merchant seamen") "as a memorial to the devotion of the men of the Mercantile Marine during the Great War [1914-18]"; they had then cost $£ 135000$ and this sum had been "voluntarily subscribed from all over the Empire". The SHS had not been consulted about this new lease; when the Ministry of Health took over these buildings from the SHS (on the "appointed day"), there was in fact a lease (from the Admiralty) in operation which was not due to expire until $2024 .{ }^{26}$ Furthermore, there was a provision in that lease for the Admiralty to pay compensation to the SHS "if the Admiralty [terminated] the lease at six months' notice".

The new lease (Murrant continued) contained provisions under Clause 6(a) and (b) under which it "may be determined by the Admiralty in certain eventualities, or by the Minister of Health if at any time the said premises are not

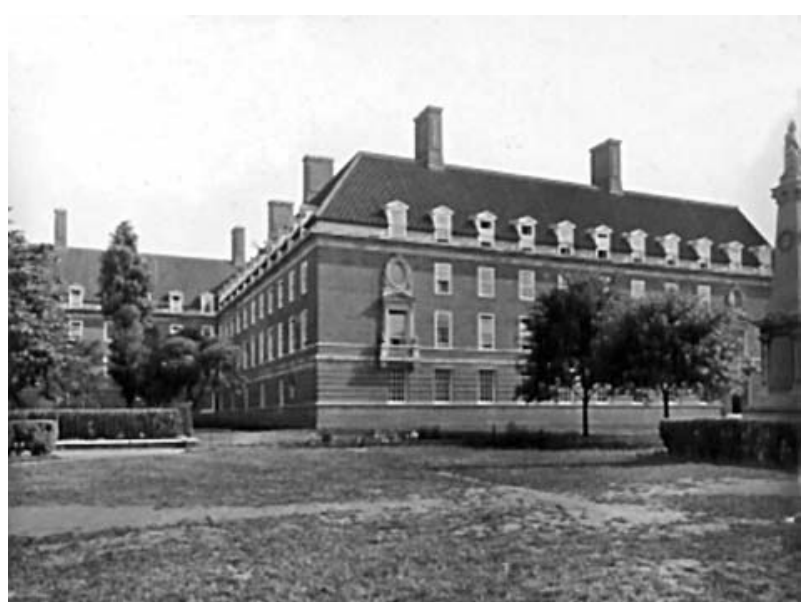

Figure 3 The Devonport Nurses' Home (part of the SHS's "additional buildings" ${ }^{\prime \prime}$ - opened in 1929, and established by voluntary contributions as a memorial to men of the British Maritime Service who served in the Great War (1914-18). (Reproduced with permission, the Seamen's Hospital Society.)

required for Hospital purposes". Murrant also referred to Clause 7 which provided "that in the event of the termination of the lease by either party, the Admiralty will repay to the lessee such sums as have actually be [sic] expended by the lessee (that is, the Minister) or by the [SHS] in the erection (with the approval of the Admiralty) of new buildings etc, etc". This meant that if the old lease was terminated by the Admiralty, compensation for the Devonport buildings would be payable to the SHS, whereas under the new lease, the Admiralty would pay to the Minister "the monies spent by the [SHS] in the erection of the Nurses Home, etc".

Murrant ended his letter to the Minister: “...in the event of the Minister of Health deciding that [the additional premises'] are no longer required for hospital purposes, regulations under Section 6(5) of the [NHS Act] would provide for apportionment as between [the SHS] and the Minister for the buildings erected by the [SHS] and by the Minister respectively" ${ }^{27}$

This matter assumes significance today for not only has the Dreadnought hospital ceased to be used as a hospital (in 1986), but the "additional buildings" have also ceased to be used for "hospital associated" purposes. Both have in fact been taken over by the University of Greenwich; the former is used as a library and computer centre, and the latter for student accommodation and conference centre use.

MacLeod duly replied to Murrant on 10 December 1954. He pointed out that under the terms of the NHS Act, not only hospitals but also "additional premises" automatically passed to the Minister on the appointed day. He referred to Regulation 27 of the NHS (Apportionment and Transfer Regulations) 1948, and wrote: "In the event of any repayment the money would be made over to the Minister of Health whether he or the [SHS] had been responsible for the cost of erection of the buildings which formed part of the whole hospital premises". ${ }^{28}$ This immediately brought forth a letter from Murrant to MacLeod: "...I imagine you will not be surprised if I say that the views expressed in your letter are, in my opinion, open to argument at least on moral grounds, and may be on legal grounds as well" (my italics). ${ }^{29}$ Following a meeting of the SHS Management Committee, Murrant again wrote to MacLeod: "...I imagine you will not be surprised to learn that my Committee regarded the position as it now stands as exceedingly unsatisfactory". He continued: “... what happens if, and when, you decide that these "additional premises" are no longer required for hospital purposes? ...my 
submission is that your Ministry had no right whatever...to enter into a new lease which creates a fundamental alteration, in the sense that the compensation payable in certain eventualities is alienated from the [SHS] to whom such compensation would be payable under the lease which was transferred to your Ministry under the terms of the [NHS Act]". He continued by reiterating that any compensation resulting from the "additional premises" being used for another purpose, belonged to the SHS and not the Minister. Murrant ended: "...we feel that in this matter of the new lease...we have been treated in an unfair and arbitrary manner without any real reason or justification...". ${ }^{30}$

MacLeod, in his reply dated 10 March 1955, pointed out: "This is ...only one example of the kind of transfer of interest which took place on a very large scale on 5 July 1948. There are many cases in which buildings put up out of voluntary funds as a memorial, and intended for use for specific purposes were transferred to the Minister with the possibility that the lapse of time and the development of hospital services in other directions might render them unnecessary or, at the very least, usable for only quite different hospital purposes". MacLeod ended: "You are suggesting...that I should take steps to ensure that the payment contingent on the disuse of the 'additional premises' should be made to the [SHS] and not to the Minister. I have no power of any kind to do this; but even if I had, it would clearly be quite indefensible for me as Minister to forego this particular right which was transferred to me in $1948^{\prime \prime} .{ }^{31}$

Murrant duly replied to MacLeod: "We shall let the matter rest for the time being...but this must not be interpreted in the sense that we accept the position... although we disagree with your Ministry's conclusions, and we must reserve the right to re-open the matter". He concluded his letter "with a formal protest and dissent from your ruling". ${ }^{32}$ To end this correspondence, MacLeod duly replied, curtly, to Murrant with the words: "...I understand your position". ${ }^{33}$

\section{EPILOGUE}

In the first example, procrastination on the part of the Minister deprived the Hospitals for Incurables of major financial income. The subscribers and other benefactors, not surprisingly, declined to support the organisations financially while their future was exceedingly uncertain. In the second example, nationalisation, and transfer of each of the Society's properties to the most appropriate Regional Board led to fragmentation, and eventually to virtual demise of the SHS. The confiscation of the Devonport buildings, which were paid for by voluntary contributions the world over, without any compensation either then or now, seems particularly unjust, especially as they are now (some 50 years later) in use for highly profitable purposes which have nothing to do with the NHS or even of health. One would have thought that there should have been a (legal) clause in the Act allowing compensation when a property no longer had a role in the NHS.

NB: References 9-19 are reproduced by permission of the archivist of the Special Collections Division, the Hartley Library, University of Southampton.

\section{REFERENCES}

1 Bevan A. In place of fear. London: Quartet Books, 1990:98-121.

2 Rivett G. Bevan and the National Health Service, 1945-1948. The development of the London hospital system. London: King Edward's Hospital Fund for London, 1986:264-78.

3 Fraser D. The creation of the British welfare state, 1940-1948. The welfare state. Stroud, Gloucestershire: Sutton Publishing, 2000:60-94.

4 Powell D. The Metropolitan Asylums Board and its work, 1867-1930. London: MAB, 1930:106.

5 Anonymous. The LCC, hospitals: a retrospect. London: London County Council, 1949:158.

6 Foot M. Aneurin Bevan 1897-1960. London: Victor Gollancz, 1997, 286361. The Rt Hon Aneurin Bevan, PC, MP (1897-1960) was the labour Minister of Health from 1945 until 51. He was subsequently Minister of Labour and National Service.

7 Richardson H, ed. English hospitals 1660-1948: a survey of their architecture and design. Swindon: Royal Commission on the Historical Monuments of England, 1998:222

8 Morrison K. The workhouse: a study of poor-law buildings in England. Swindon: Royal Commission on the Historical Monuments of England, 1999:255.

9 Wolfe JA. Opinion 18 November 1947:2.

10 Slowe M to The Secretary, Ministry of Health. 19 November, 1947:2.

11 Gedling R to Slowe M. 5 December 1947:1.

12 Gedling R to Slowe M. Undated 1.

13 Gilbert S to Subscribers. Undated, 1.

14 Slowe M to The Secretary, Ministry of Health. 20 April, 1948:2.

15 Radcliffe C, Wolfe JA. Joint Opinion 25 April 1948:2.

16 Slowe M to Gilbert S. 16 July 1948:1

17 Gilbert S to Slowe M. 7 October 1948:1.

18 Rabbi Sir Israel Brodie to Aneurin Bevan, MP. 6 January 1950:2.

19 Arbitration between: Minister of Health and The Trustees of the Home and Hospital for Jewish Incurables. 7 March 1950:3.

20 Cook GC. Victorian incurables. a history of the Royal Hospital for Neurodisability, Putney. Durham: Memoir Club, 2004:216-27.

21 Cook GC. The Seamen's Hospital Society. From the Greenwich hulks to Old St Pancras. A history of tropical disease in London. London: Athlone Press, 1992:33-67.

22 Cook GC. The Seamen's Hospital Society: a progenitor of the tropical institutions. Postgrad Med J 1999;75:715-7.

23 Sir Ernest Henry Murrant, KCMG (1889-1974) was Chairman of the Board of Management of the Seamen's Hospital Society from 1946 until 67. He had been President of Council of the Chamber of Shipping, and Chairman of the General Council of British Shipping. He was also an Honorary Member of the Honourable Company of Master Mariners.

24 The Rt Hon lain Norman MacLeod, PC, MP (1913-70) was Conservative Minister of Health from 1952 until 55. He was subsequently Secretary of State for the Colonies, Chancellor of the Duchy of Lancaster, and Chancellor of the Exchequer-a post which he held at his sudden and unexpected death.

25 The new lease was dated 24 September 1954, and ran for $71 \frac{1}{2}$ years from 24 June 1953. It also covered "the Dreadnought Seamen's Hospital and additional premises at Greenwich"

26 This original lease was dated 9 May 1936, and ran for 90 years from 25 December 1934; it covered "existing Hospital and additional premises at Greenwich".

27 Murrant EH to MacLeod IN. 17 November 1954:2 [SHS Archive]

28 MacLeod I to Murrant E. 10 December 1954:1 [SHS Archive].

29 Murrant EH to MacLeod I. 13 December 1954:1 [SHS Archive]

30 Murrant EH to MacLeod I. 21 January 1955:2 [SHS Archive].

31 MacLeod I to Murrant E. 10 March 1955:1 [SHS Archive].

32 Murrant EH to MacLeod I. 24 March 1955:1 [SHS Archive]

33 MacLeod I to Murrant E. 29 March 1955: 1 [SHS Archive]. 